Wacana Vol. 20 No. 1 (2019): 15-31

\title{
Southeast Asian manuscripts from the collection of Sir Hans Sloane in the British Library
}

\author{
ANNABEL TEH GALLOP
}

\begin{abstract}
Sir Hans Sloane (1660-1753) was the founding father of the British Museum and its Library, which later became the British Library. Sloane's vast collections of natural history specimens, coins, medals, ethnographic items, and books included four thousand manuscripts, twelve of which were from Southeast Asia. These twelve Southeast Asian manuscripts, including eight from the Indonesian archipelago, are described in detail here. Although Sloane is not known to have had personal connections with Southeast Asia or any particular interest in the region, this small collection nonetheless encompasses an exceptionally wide range of the languages, scripts, writing supports and books formats found in the region, manifest in some of the earliest manuscripts known in certain genres.

KEYWORDS

Sir Hans Sloane; British Library; British Museum; Southeast Asia; manuscripts; documents; Arabic; Javanese; Malay.
\end{abstract}

\section{Sir HANS SLOANE, COLLECTOR EXTRAORDINAIRE}

Of the many passionate collectors active in the heyday of the "cabinets of curiosities" era, Sir Hans Sloane (1660-1753) is widely acknowledged as one of the greatest. A physician by profession, Sloane's voluminous collections were, not suprisingly, especially strong in natural history, notably botanical and zoological specimens, seashells, and anatomical rarities, but he also collected coins and medals, gemstones, scientific instruments, books and unusual objects of interest. When Sloane died in 1753, he bequeathed his entire collection to

AnNABEL TEH Gallop is Head of the Southeast Asia section at the British Library, London. She works on Malay and Indonesian manuscripts, documents, letters and seals, and the art of the Islamic book in Southeast Asia. Her publications include Golden letters; Writing traditions of Indonesia (with Ben Arps, 1991), The legacy of the Malay letter (1994), Lasting impressions; Seals from the Islamic World (with Venetia Porter, 2012), and Malay Seals from the Islamic World of Southeast Asia (forthcoming, 2019). Annabel Teh Gallop may be contacted at: annabel.gallop@ bl.uk. 
the nation in return for the payment of a modest sum of $£ 20,000$ to his heirs, on condition that a new public museum be created to house it. This led to the founding of the British Museum in 1753, and Sloane's collections also underpin the subsequently formed Natural History Museum and the British Library.

Sir Hans Sloane's library comprised some 50,000 volumes including over four thousand manuscripts, which have been described with some understatement as "very heterogenous" (Hunt 2012: 190). In this collection were twelve manuscripts from Southeast Asia. Seven are from the archipelago, with two in Malay - one probably from Ambon, and the other from Java and three in Javanese, one in Balinese and a fragment in Old Javanese. From mainland Southeast Asia, there is a manuscript in Pali probably from Thailand, a royal letter from Vietnam, and a group of trading permits from Burma (Myanmar). Each of these manuscripts will be described in detail below. ${ }^{1}$

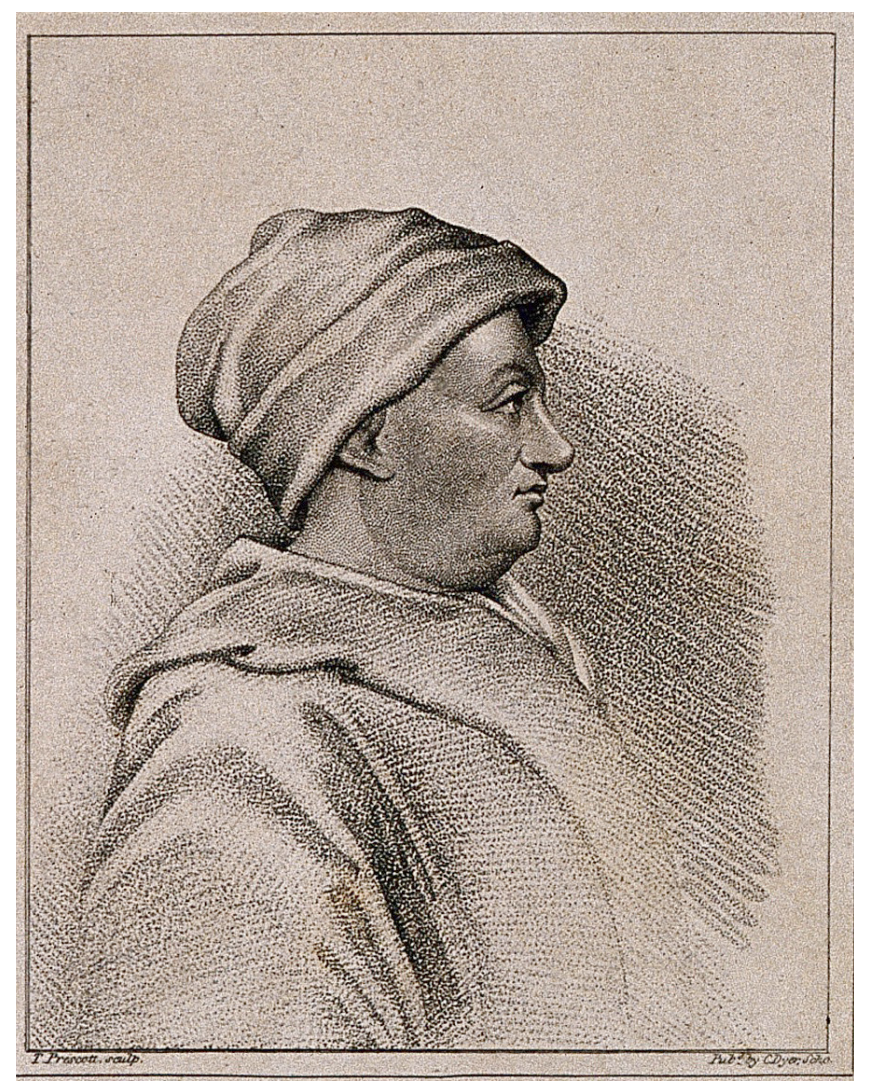

Figure 1. Sir Hans Sloane. Stipple engraving by T. Prescott. (Wellcome Library, ICV No. 5682L. Courtesy of Wellcome Images).

1 This article on the Southeast Asian manuscripts in the Sloane collection in many different languages could not have been written without help from many quarters. I would like to express my profound appreciation to I Nyoman Argawa, Sud Chonchirdsin, Th. van den End, Arlo Griffiths, Emma Harrison, Jana Igunma, Arlo Khazeni, San San May, and Dick van der Meij, whose individual contributions are acknowledged within the text. 


\section{Sloane 3115: A Malay Psalter}

The two Malay manuscripts in the Sloane collection are very different in both content and form. Sloane 3115 is a collection of Christian hymns, psalms, and services, in Malay in Romanized script. A note in Dutch in a seventeenthcentury hand on the flyleaf names the owner of this book as Cornelius van der Sluijs, who in the year 1672 sailed on the ship "The coat of arms of Alkmaar" to the East Indies, as a church comforter of the sick. ${ }^{2}$

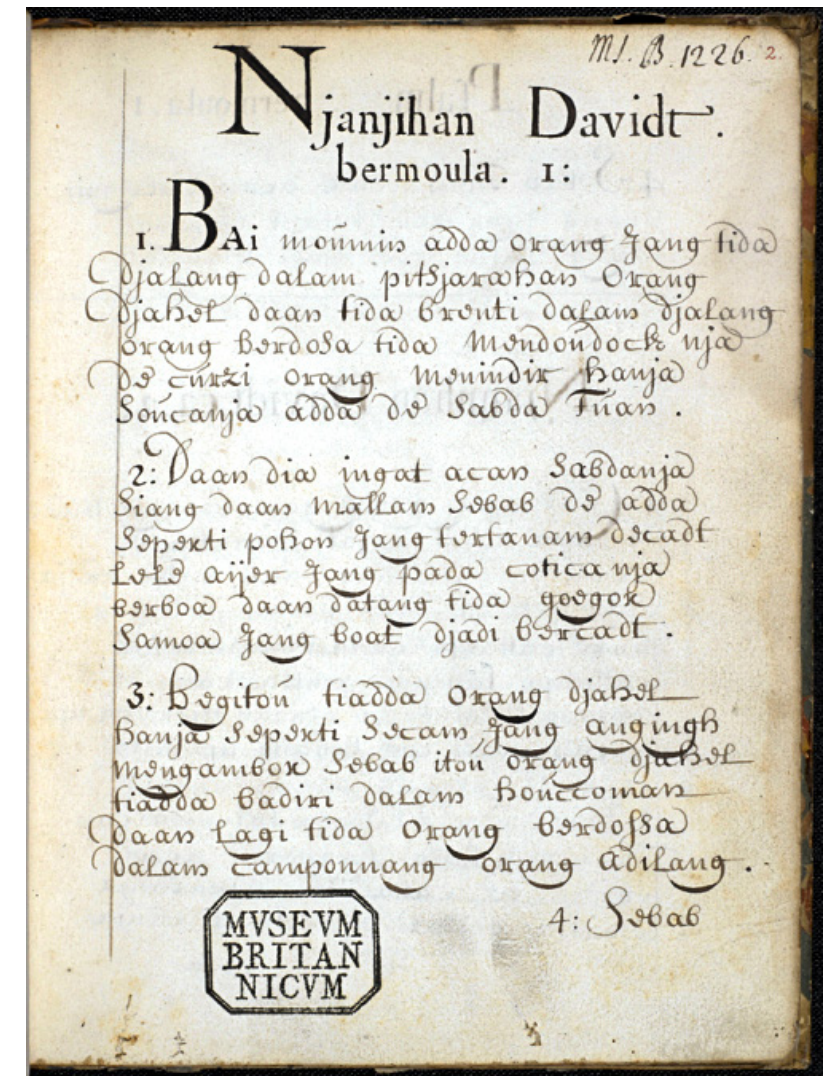

Figure 2. The first page of the Psalms of David in Malay, showing the distinctive octagonal black ink British Museum stamp designed for use on Sloane's library. (British Library, Sloane 3115, f. 2r).

According to notes kindly provided by Th. van den End, ${ }^{3}$ Cornelius van der Sluijs was born circa 1648 at Sluis, in the Dutch part of Flanders, and matriculated in 1665 in the theological faculty at Utrecht, although he probably never finished his studies. He sailed to the Indies as noted above in 1672, and in July 1673 was posted to Ambon where he was immediately appointed "proponent" minister, giving him a licence to compose his own sermons, but not to administer the sacraments. On 10 April 1678 Van der Sluijs took his final church exams, at last becoming a minister with full rights, and served in this capacity with the church in Ambon until 1684. From 1684 to 1690 he

2 Cornelius van der Sluijs, Ultraijectinus. In 't Jaar 1672 voor krankbezoeker met 't Wapen van Alkmaar naar Oost-Indien gevaren. In 't Jaar 1678 tot peremptoir onderzogt, en als absoluit predikant na Ternaten beroepen. In perpetuam mem. tesseram. Posui C. v/d Sluijs. (Sloane 3115, f. 1r).

3 Personal communication, Th. van den End, 2-10-2015; compare Gallop 2018a. 
held the same position in Ternate, and from 1690 to 1697 in Batavia. He then spent five years back in the Netherlands, but in 1702 was again in Batavia, where he died in 1715.

Van der Sluijs was well known for his knowledge of Malay, and while in Batavia in the last decade of the seventeenth century he worked on revising the Bible translation of Leydecker and Van der Vorm. However, he is not personally recorded as having submitted translations to the church council in Ambon or Batavia, and there is no evidence that the Malay hymns in this volume are his own work. Van den End indeed suggests that discernible Portuguese influence in the vocabulary points towards a much earlier date of translation, perhaps from the first half of the seventeenth century, indicating that the contents of this volume were probably copied from existing manuscript or printed sources. It is most likely that the manuscript was compiled in the Moluccas to mark the important occasion of Van der Sluijs' appointment as a full minister in Ambon in 1678, making him not only the leader of his own church, but also the third highest official in the local VOC hierarchy.

\section{SlOANe 2393: An early Malay text On Islamic LaW}

The other Malay manuscript in the Sloane collection, Sloane 2393, is a short legal text (undang-undang) based solely on Islamic law, shari'a, rather than Malay traditional law (adat). This manuscript was published by Mohamad Jajuli Rahman (1986), who noted that it differs from most other early Malay Islamic texts on figh by focussing on criminal law (hukum jenayah) and presenting the varying punishments for murder, injury, adultery, slander, theft, and banditry. It differentiates between qișāss, equivalent punishments of the form "an eye for an eye", diya 'blood money', hadd, punishments prescribed in the Qur'an and Hadith, and kaffära, atonement punishments. It explicitly cites two sources - Kitāb al-Basiț by al-Ghazālì and al-Muharrar by al-Rāfi ${ }^{1} \overline{1}-$ but also draws upon a number of other well-known and widely used works on figh such as Nawawī's Minhāj al-Țälibìn. ${ }^{4}$

The physical form of this manuscript is highly unusual in that the Malay text in Jawi (modified Arabic) script is written on watermarked European paper lengthwise across the page, parallel to the spine of the book, in landscape format. This suggests that the manuscript may have originated in a region and at a time where paper codices were just beginning to be introduced into a writing culture where palm leaf - with its horizontal format - was the standard writing medium. A few characters in Javanese script on the cover (f. $21 \mathrm{v}$ ), the frequent use of the Javanese letter dha (dal with one dot underneath), and a high incidence of Javanese words in the Malay text hint at an origin in Java. ${ }^{5}$ The Jawi hand is fluent and cursive, but with certain letter-form features which are associated with the oldest known Malay manuscripts, such as the placement of three dots underneath final nya, and under ga. 
The watermark is an icon of a two-armed round pot bearing the letters $\mathrm{G} \mathrm{H}$, on a pedestal, containing a spray of five tulip-like flowers. ${ }^{6}$ Pot watermarks, of which many varieties have been documented, were extremely common in English and French papers from the sixteenth and seventeenth centuries, and a pot watermark is also found in one of the earliest Malay manuscripts known in Cambridge University Library, Dd.5.37, a copy of Hikayat Nabi Yusuf dated $1604 .^{7}$ The shape of the pot in the watermark in Sloane 3115 is fairly standard, but the floral forms have not yet been identified from any watermarks register. Taken together, all these features suggest a relatively early date for this manuscript, most likely in the seventeenth century.

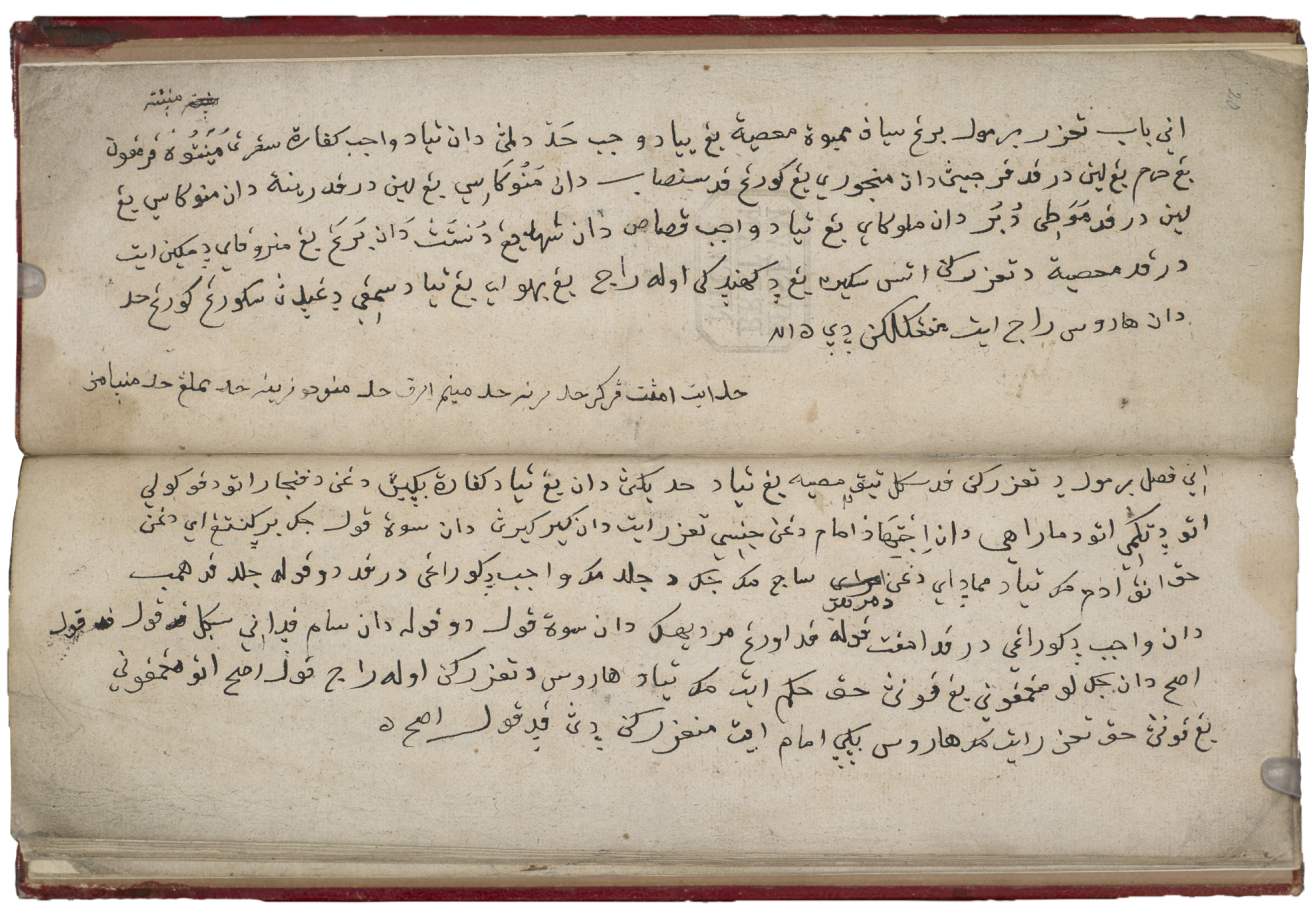

Figure 3. The opening pages of the Malay legal text on punishment in Islamic criminal law. (Sloane 2393, ff. 19v-20r).

\section{SLOANe 2645: A JAVANESE DLUWANG MANUSCRIPT OF BAPADAL}

The earliest dated Southeast Asian manuscript in the Sloane collection is another early Islamic legal work, from Java. This is an accomplished copy of a standard Arabic text of the Shafi' 1 s school of law by the Yemeni scholar 'Abd Allāh bin 'Abd al-Raḥmān Bā Fạ̣l (d. 1512), Muqaddimah al-Haḍramiyyah, 'The Hadrami Introduction (or Prolegomenon)', on prescriptions concerning worship like ritual cleanliness, prayer, zakat, the fast, and the hajj. This work is also known as Masā'il al-ta'lim, 'Questions for instruction', as entitled in this manuscript, but is also more generally referred to as Mukhtașar Bā Faḍl, 'The

\footnotetext{
6 I am most grateful to Genie Yoo and Evyn Kropf for many suggestions of comparable watermarks, and references to helpful sources; compare also Mohamad Jajuli 1986: 2.

7 Russell Jones 2011 < http:/ / www.paperhistory.org/jones.pdf>; with thanks to Genie Yoo for this reference.
} 
concise legal handbook of Bā Faḍl', or in Java simply as Bapadal. A number of other manuscripts from Southeast Asia of this work are known, of which Sloane 2645 is by far the oldest. ${ }^{8}$

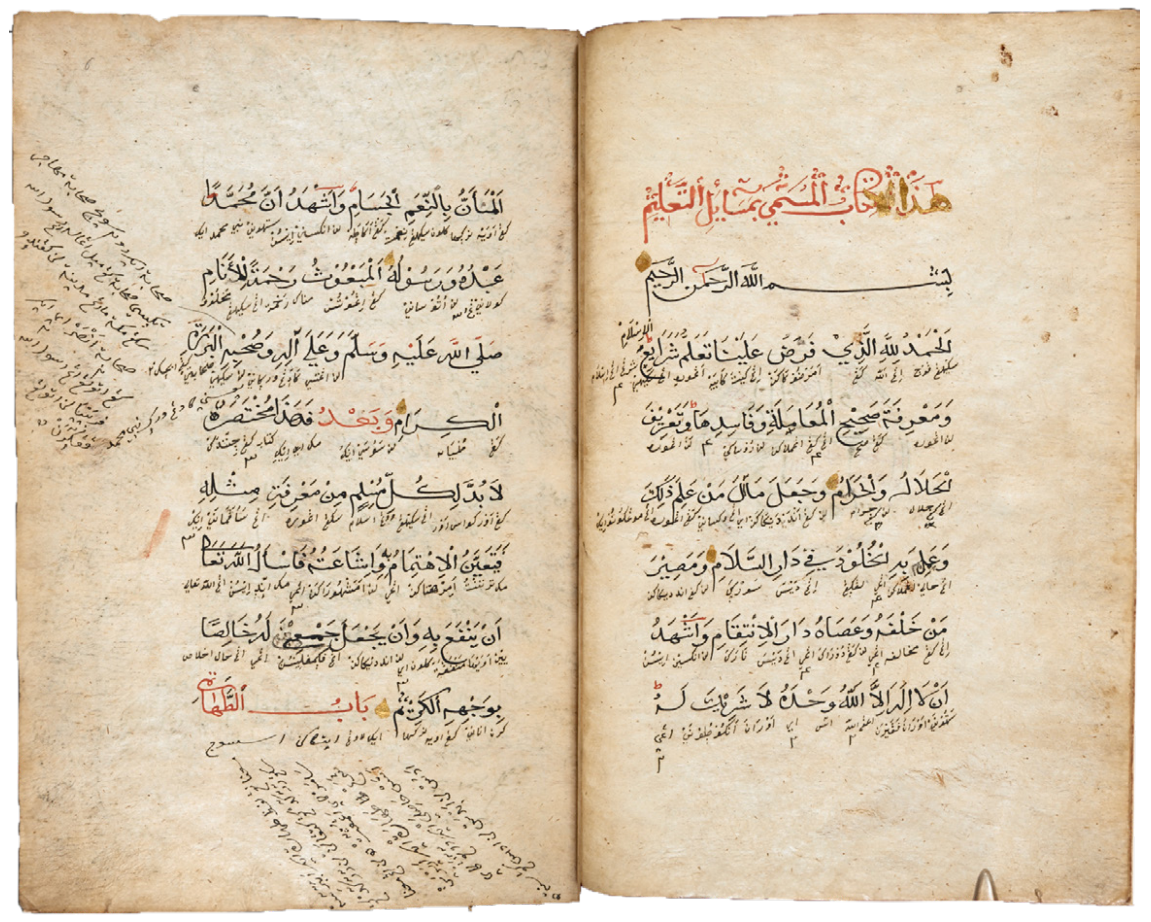

Figure 4. Opening pages of Masā'îl al-ta'lìm by Bā Faḍl, Arabic text with interlinear Javanese commentary, 1623. (British Library, Sloane 2645, ff. 5v-6r).

This manuscript was copied by a scribe named 'Abd al-Qadīm, and is clearly dated at both beginning and end of the volume with the numerals 1545 signifying the Javanese Era - an Islamized lunar form of the Indic Saka era - equivalent to 1623/4 AD. The writing of the date is of great interest, as the units of the numerals are indicated through a system of dots: thus " 1 " is followed by three dots indicating a unit of thousands; " 5 " by two dots indicating hundreds; " 4 " by one dot indicating tens; and then the final digit " 5 " without any dots. ${ }^{9}$ In Sloane 2645, the date of 1545 is also given in the abjad system, represented by the letters alif-ha-dal-ha, read left to right. ${ }^{10}$

The Arabic text is written in a large hand in widely-spaced lines, leaving room for a slanting interlinear translation in Javanese in Arabic (Pegon) script, which has been filled in for the first half of the book, from ff. $5 \mathrm{v}$ to $84 \mathrm{v}$. Following the digitization of this manuscript, a new edition of this Javanese translation has just been published by Yahya, Hasan, and Farkhan (2018).

Considering its relatively early date for a manuscript from maritime Southeast Asia, this complete copy is in excellent condition. The cursive hand

8 Compare Yahya, Hasan, and Farkhan 2018: 3.

9 This system of indicating the place-value of numerals is also found in two seals from Ternate dated 1715, and two from Dompu dated 1786 and 1788, see Gallop 2015: 109.

10 Yahya, Hasan, and Farkhan 2018: 31-33. 
is accomplished and fluent; gold illumination has been applied sparingly to the opening lines on the first page - a very rare feature in Islamic legal texts from the Malay world - and rubrication is found throughout. Although earlier Javanese manuscripts are known which are also written on dluwang, Javanese paper made from the beaten bark of the mulberry tree, this may be one of the earliest dated such manuscripts. ${ }^{11}$

\section{SlOANE 1403A AND 1403E: JAVANESE FINANCIAL DOCUMENTS}

The two other Javanese manuscripts in the Sloane collection are both short documents relating to financial matters, and both testify to the long-standing Chinese mercantile presence in Java. Sloane 1403A (see Figures 5a and 5b) is a single trimmed palm leaf, possibly from the north coast of Java, incised on one side with two lines of uninked Javanese text, the meaning of which is unclear: Punika piaga kawula, saking ratu baguwarnana gangsar kawula abatad / Rĕginsa kawula, pilaber dhar tigang tir??? Puka parisardeneki, pa. ${ }^{12}$ On the reverse is an uninked incised note in Chinese, a record of the purchase of four cows. The text is dated 乙未年正月初五日, 'Fifth day of first month of yi wei year'. As the year is only given in the twelve-year Chinese zodiacal cycle, taking into account the dates of the Sloane collection, this date is most likely to be equivalent to either 10 February 1655 (Shunzhi reign) or 8 February 1715 (Kangxi reign). ${ }^{13}$

The second Javanese document, Sloane 1403E (see Figures 6a and 6b), is written not on palm leaf but a small piece of bamboo, with two lines of Javanese incised on one side with further annotations in Javanese and Lampung script. The Javanese text is obscure but may be a reminder of a purchase of rice with the price of 1 reyal: Pengĕt. Cili bĕsar angadĕlakĕna utap ri ... wolap lëbaga, pat, sasine sahĕkare. / Anyahur bĕras nĕnĕp rare sarehal, ta. Ta. Bwa. ??? tiga wulan. ${ }^{14}$ On the other side is a note written in black ink in Chinese, probably a record of an account. The text is dated 戊子年四月十四日, 'fourteenth day of fourth month of wu zi year', equivalent to either 6 May 1648 (Shunzhi reign) or 2 June 1708 (Kangxi reign). ${ }^{15}$

11 Compare Leiden Cod.Or. 1928, before AD 1598 (Van der Meij 2017: 50).

12 Javanese text read by Dick van der Meij.

13 Chinese text read by Emma Harrison.

14 Javanese text read by Dick van der Meij.

15 Chinese text read by Emma Harrison. 

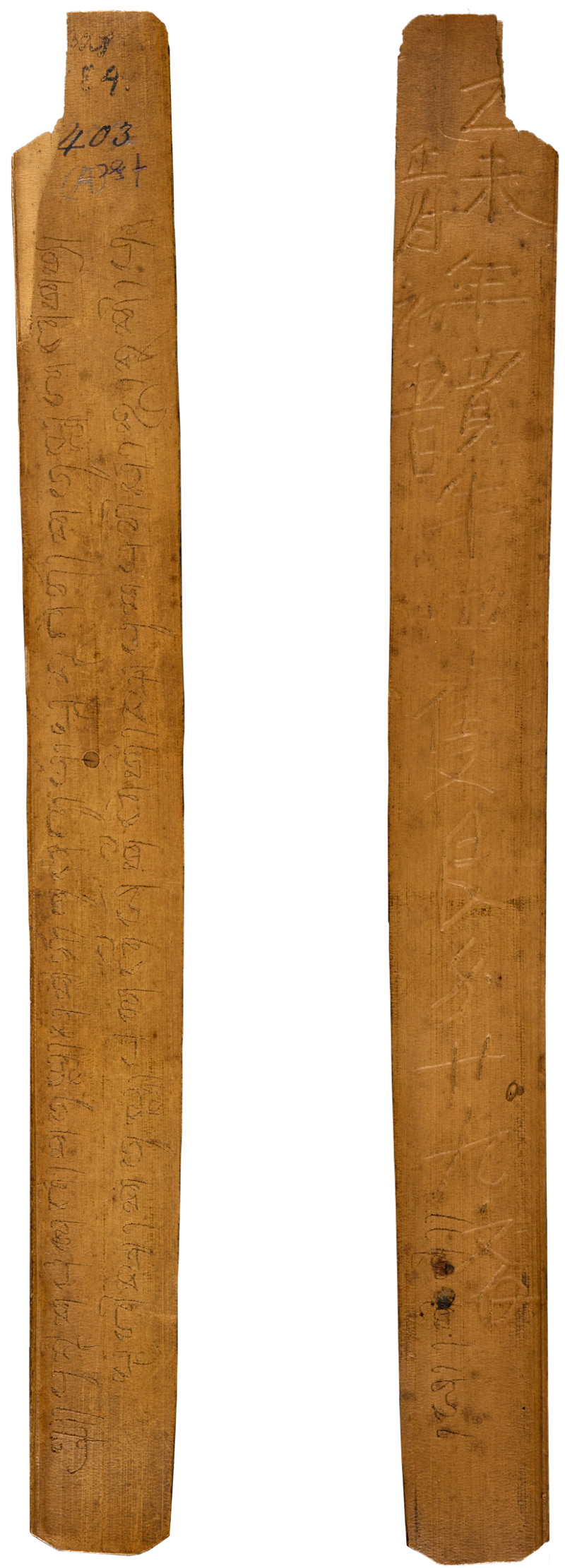

Figures $5 \mathrm{a}$ and $5 \mathrm{~b}$. Account for the purchase of four cows, with text in Javanese on the recto and in Chinese on the verso. (British Library, Sloane 1403A). 

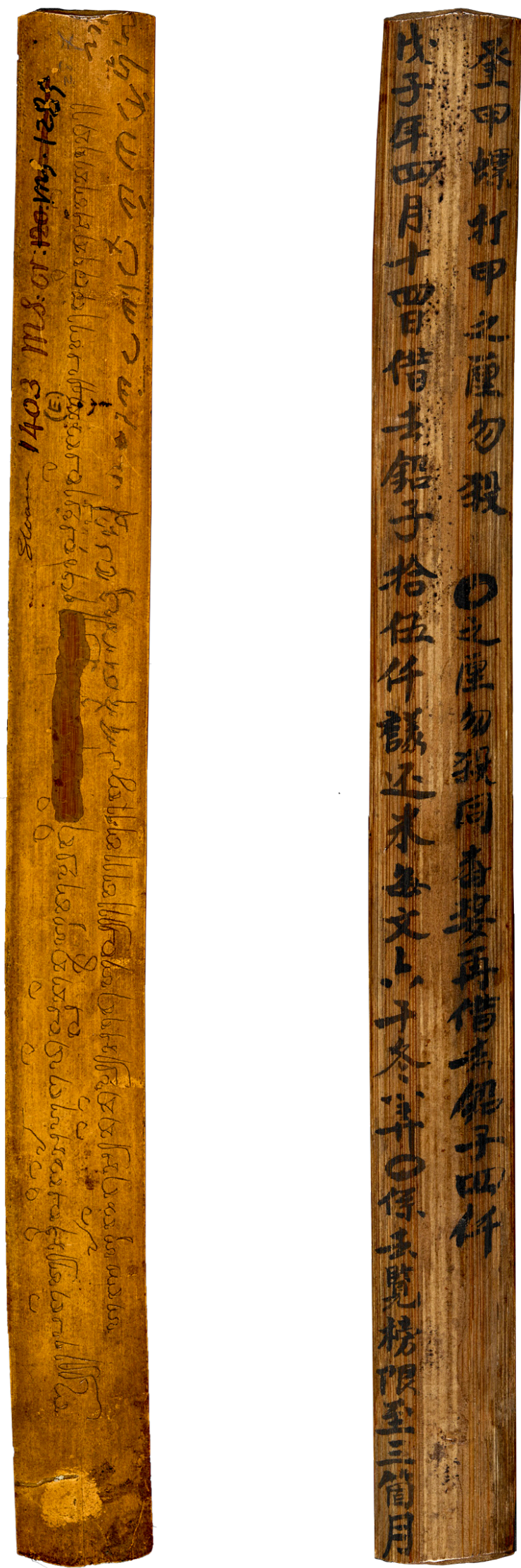

Figures $6 \mathrm{a}$ and $6 \mathrm{~b}$. Front and reverse of a financial account, with text in Javanese, Lampung, and Chinese [1708]. (British Library, Sloane 1403E). 
Figure 7. A Balinese record of a debt. (British Library, Sloane 1035).

Long believed to be Javanese and catalogued as such, ${ }^{16}$ Sloane 1035 has recently been identified by Dick van der Meij and I Nyoman Argawa as being in Balinese language and script. ${ }^{17}$ It comprises a single tapered piece of folded palm leaf, with two lines of writing on one side only, regarding a debt between a Chinese and Anom Wahitin:

Pengĕt. si Cina Kamasan, asambutan tigang puluh reyal, isi Anom Wahitin / Kasahuran saking Ratu Kilen. Titi.

'Reminder. The Chinese from Kamasan has taken 30 reyal from Anom Wahitin/ Ordered by Ratu Kilen. End.' ${ }^{\prime 18}$

This format of palm leaf, folded along the spine, is known as embat-embatan. ${ }^{19}$ Sloane 3480: An Old Javanese fragment of the ArJunavijaya

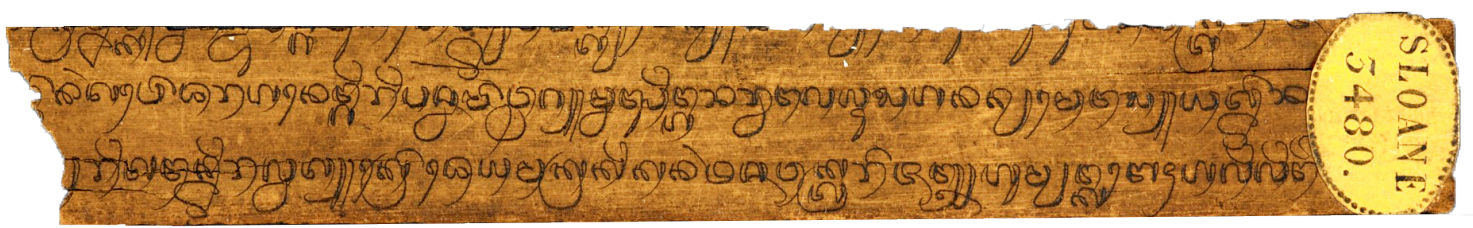

Figure 8. Fragment of the Arjunavijaya in Old Javanese in Balinese script, on palm leaf. (British Library, Sloane 3480).

For over two centuries Sloane 3480, a small piece of palm leaf with text in Old Javanese, remained unidentified, ${ }^{20}$ until in 2018 it was digitized and featured in a post on the British Library's Asian and African Studies blog. ${ }^{21}$ Within 24 hours, a small team of scholars located across the globe - Ida Bagus Komang Sudarma in Bali, Wayan Jarrah Sastrawan in Sydney, and Arlo Griffiths in Lyon - had worked together to read and identify the fragment, and their results were published the next day on the same blog, on which source the

17 Pers. comm., Dick van der Meij, 16-12-2018.

18 Balinese text read and translated by Dick van der Meij and I Nyoman Argawa.

19 Van der Meij 2017: 193-194.

20 Compare Ricklefs and Voorhoeve 1977: 177.

21 Gallop 2018b. 
following comments are based. ${ }^{22}$

The manuscript is in Old Javanese - an early form of the Javanese language characterized by an exceptionally high proportion of Sanskrit words - written in Balinese script, and is undated. The surviving manuscript fragment represents less than half of the right side of a single palm leaf (lontar), and would originally have had a string hole in its middle, as it still does in its right margin. In its original condition, the leaf would have had four lines of writing on each side. The text can now be identified as part of the Arjunavijaya, the court poem (kakawin) composed by Mpu Tantular in the fourteenth century in the Kingdom of Majapahit. A critical edition of this important classic of Old Javanese literature, with English translation, was published by Supomo (1977). The surviving lines on Sloane 3480 contain parts of stanzas 12, 14, $15,16,17,18,19$, and 20 (but not of stanza 13) from canto 10, and describe a confrontation between Śiva's attendant Nandiśvara and the ten-faced demon Rāvana. A full diplomatic edition of these lines is given in Sudarma, Sastrawan, and Griffiths (2018), and the pre-1753 dating of Sloane 3480 makes this leaf one of the oldest known witnesses for the Arjunavijaya (compare Arps and Van der Molen 1994).

\section{SLOANE 4099: A BudDhist MONASTIC CODE}

Sir Hans Sloane owned four other manuscripts from Southeast Asia, originating from territories on the mainland. Also written on palm leaf is Sloane 4099, which contains a part of the Pátimokkha, the Buddhist code of monastic discipline, dating to around 1700 or earlier. Sloane's manuscript is incomplete, comprising four folios only. Each folio contains three main lines of text from the Pätimokkha in Pali, the canonical language of Theravada Buddhism, with two leaves written in Lao script, and two in Cambodian (Khmer) script with interlinear explanations. A slight variant in letter form may hint at an origin in Thailand..$^{23}$

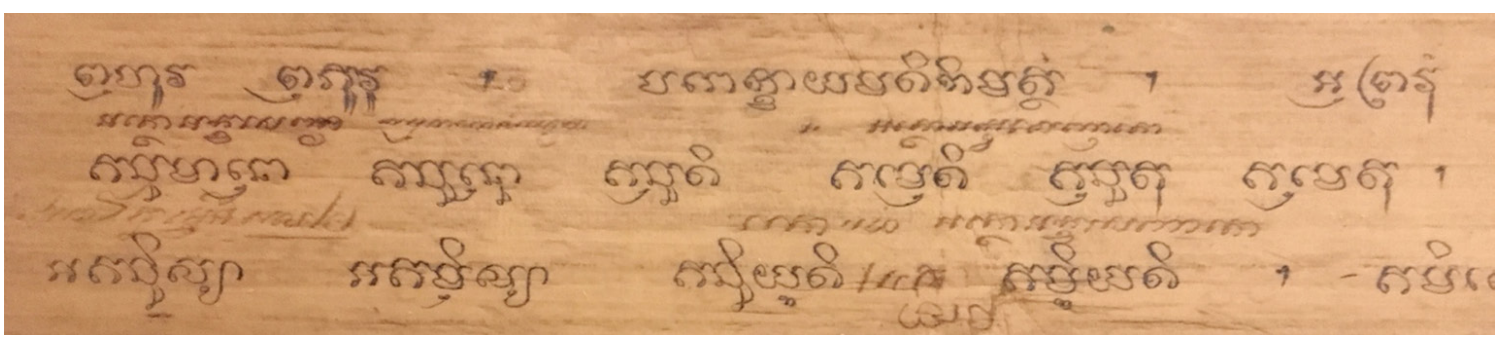

Figure 9. Section of one leaf of the Pātimokkha in Pali in Khmer script. (British Library, Sloane 4099(4)).

\section{SloAne 3460: A ROYAl VietNAMESE LETTER}

The largest and most impressive visually of all the Southeast Asian manuscripts

22 Sudarma, Sastrawan, and Griffiths 2018.

23 Pers. comm. from Jana Igunma, Henry Ginsburg Curator for Thai, Lao, and Cambodian, British Library. 
in Sloane's collection is a royal letter from the ruler of Tonkin (Sloane 3460), written in the Vietnamese language in Chinese (Han Nom) characters, probably despatched in 1673. In 1672 the first English East India Company ship arrived in Tonkin in North Vietnam, and in March 1673 the captain, William Gyfford, was permitted to meet the ruler Trinh Tac (r. 1657-1682). While the Company sought the establishment of commercial relations with Tonkin, the Vietnamese were interested in accessing new technology, and in his letter, Trinh Tac requests iron or bronze cast cannons. The letter is in the form of a scroll, written on yellow paper with beautiful silver illuminated patterns, and bears the square red ink seal of the ruler. The beginning of the scroll, which may have contained the details of the sender and addressee and the date, is missing, but a full translation of the surviving portion of the letter by Li Tana, edited by Geoff Wade, is given in Chonchirdsin (2018).

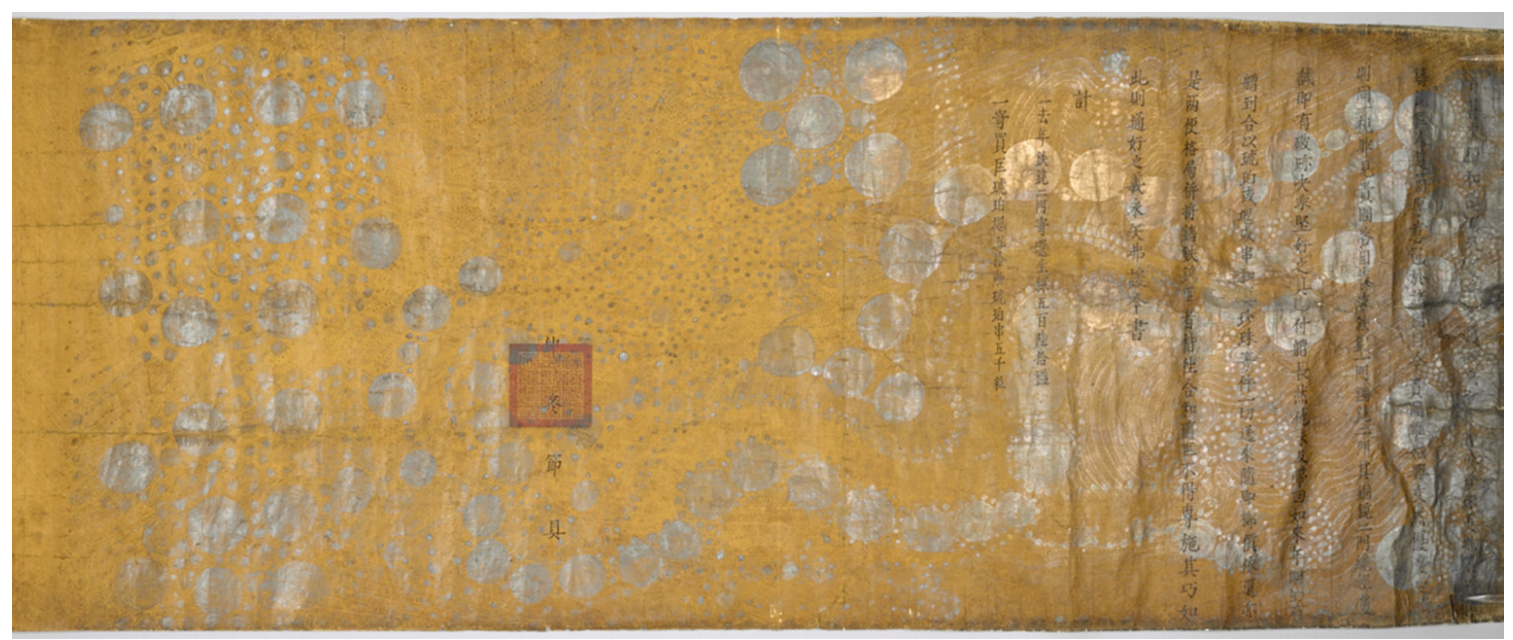

Figure 10. Illuminated Vietnamese letter with red ink seal of Lord Trinh Tac [1673]; the scroll is incomplete at the right-hand end. (British Library, Sloane 3460).

TRADING PERMITS FROM ARAKAN

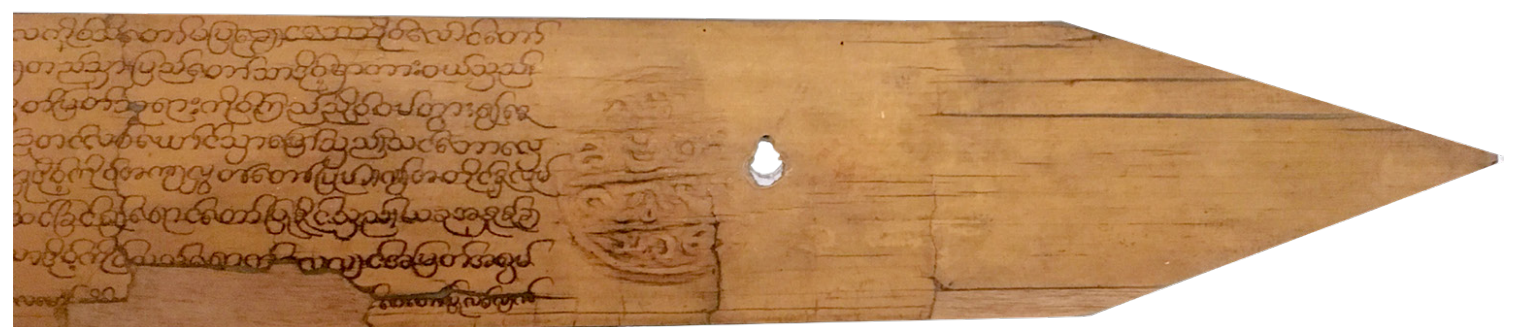

Figure 11. The pointed end of the trading permit of the king of Arakan written on palm leaf in Burmese, with his round seal, 1728. (British Library, Sloane 4098).

Of particular interest for the light they shed on chancery practice in a Southeast Asian state are two trading permits issued by King Chandrawizaya (r. 17101731) of the Arakanese Kingdom of Mrauk U, an independent state until captured by the Burmese in 1784. Sloane 4098 is a trading permit in Burmese, 
issued to a foreign trader acknowledging his gifts and permitting him to trade in Arakan, and is dated in the Burmese Era 1090 (AD 1728). It is written on a single palm leaf, tapered to a point at the right-hand end, and bearing two blind-stamped seal impressions of the ruler at the beginning and end. This is both the earliest dated palm-leaf manuscript from Burma (Myanmar) in the British Library, and, at $91 \mathrm{~cm}$ in length, the longest (Herbert 1989: 59-60).

Also found in the Sloane collection are two Persian documents from Arakan, both of which were listed in the catalogue of Persian manuscripts in the British Museum by Charles Rieu (1879: 405-406). Sloane 3259 (see Figure 12) is a trading permit from the ruler of Arakan, Chandrawizaya Rājā, dated 14 Sha'bān 1090. Rieu assumed this date referred to the Hijra Era, and thus equated it to 1679. But in an important recent study, Arash Khazeni (2018) noticed that the document was dated in the Maghi or Burmese Era, thereby redating the letter to 1728 , and revealing that the Persian document is a translation of the Burmese permit written on palm leaf noted above. It can thus be ascertained that both permits are addressed to the Armenian merchant Khwājeh George in Chennaipattana across the Bay of Bengal, giving him permission to trade in Arakan. Both bear the same round royal seal inscribed in Pali, "Supreme Lord, Master of the Golden Palace", which is blind-stamped on the palm leaf permit, stamped in black ink on the Persian document, and in red wax on its cloth envelope and paper wrapper. Sloane 3260 is a second, shorter letter in Persian to Khwajjeh George from an unnamed merchant of Arakan, without a seal, confirming and following up on King Chandrawizaya's granting of permission to trade. ${ }^{24}$

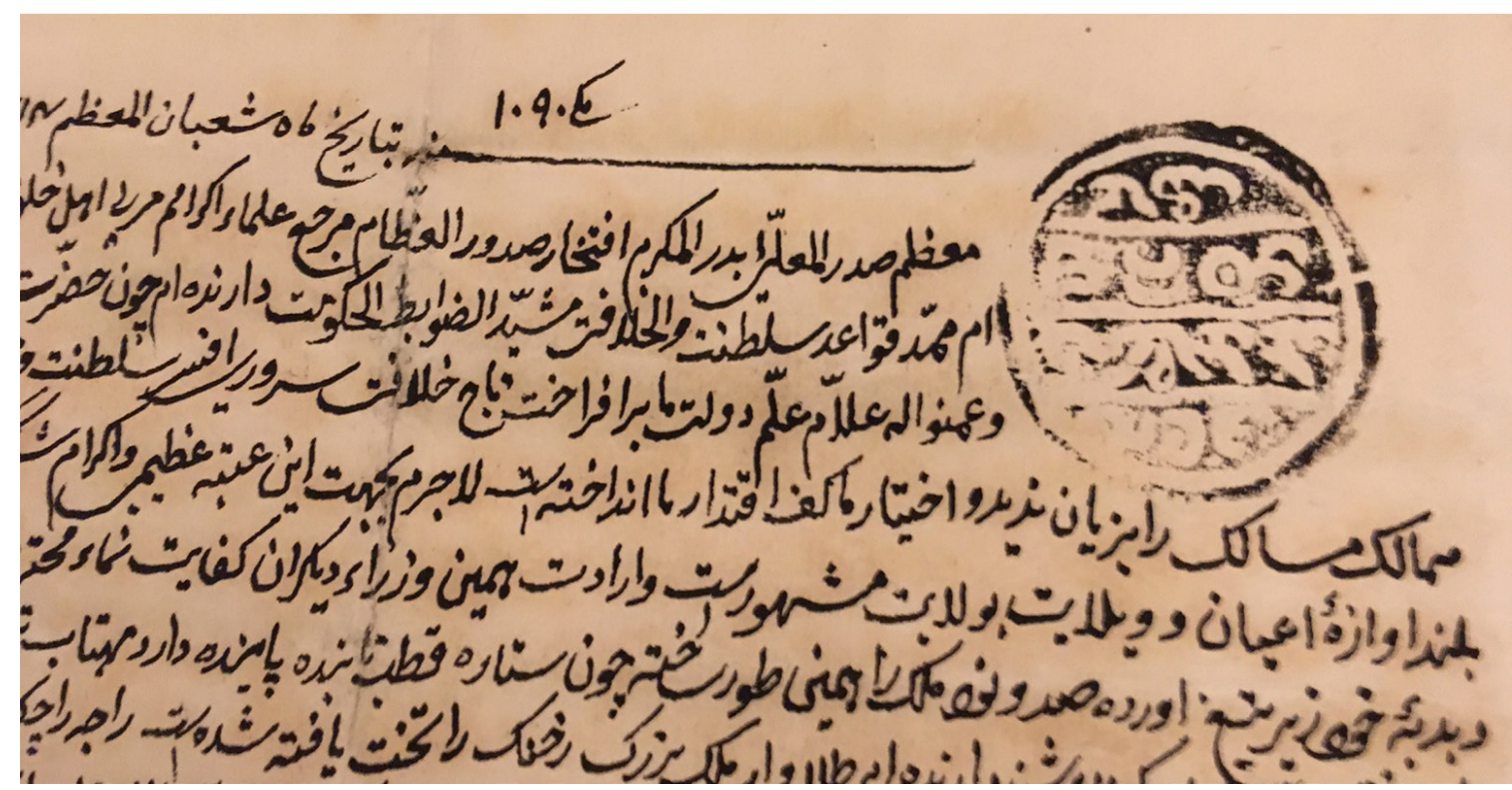

Figure 12. The seal and date 1090 in the Maghi era at the start of the trading permit from the king of Arakan, written in Persian, 1728. (British Library, Sloane 3259). 


\section{The Sloane collection of SOUtheast Asian ManUscriptS}

In addition to the twelve manuscripts described above, there are a few other Southeast Asian elements contained within other manuscripts in the Sloane collection; for example, a three-page Malay wordlist dating from around 1665 is found within a common place book belonging to a surgeon, Robert Mustow, Sloane MS 2117. ${ }^{25}$ But there are few clues as to how Sir Hans Sloane obtained his Southeast Asian manuscripts, for he is not known to have had any particular interest in Southeast Asia, or any identifiable direct personal contacts with the region.

Some of Sloane's Chinese manuscripts were known to have originated with Thomas Hyde (1636-1703). ${ }^{26}$ Hyde was the official translator to the court of Charles I and Charles II, and at the University of Oxford was appointed Reader of Hebrew in 1658, and Bodley's Librarian in 1665. Hyde had a strong interest in Oriental languages and was well known for his knowledge of Arabic, Hebrew, Persian, Syriac, Turkish, and Malay; he was responsible for the Malay translation of the Gospels printed at Oxford in 1677, and also corresponded with Thomas Bowrey, compiler of the first English-Malay dictionary which was published in London in 1701. However, none of the twelve Southeast Asian manuscripts described above are identifiable in the manuscript list of items which Sloane obtained from Hyde. ${ }^{27}$

Thus, at first sight these twelve manuscripts from Southeast Asia appear to be a rather random and inconsequential selection linked by nothing other than their geographic origin and their temporary ownership by Sloane. But viewed through another lens, they tell a narrative of astonishing richness, in the range of languages and scripts represented, materials and book formats used, and religious and calendrical traditions documented.

For its small size, the Sloane collection of Southeast Asian manuscripts encompasses an exceptionally diverse linguistic melange. The languages represented include not only major vernaculars of the region - Malay, Javanese, Old Javanese, Balinese, Burmese, and Vietnamese - but also all the major foreign languages which served the spread of both faith and trade in Asia: the Sanskritic element in Old Javanese, reflecting Hindu traditions; Pali, the language of Buddhist canonical texts of the Theravada school; Arabic, the language of the Qur' an and Islam; Persian, the official language of the Mughal empire of India and of the Indian Ocean trading network, and also a vehicle for the transmission of many Islamic literary traditions; Chinese, representing the major foreign trading and political power in Southeast Asia over the course of a millennium; Latin, the ecclesiastical and diplomatic language of Christianity, introduced to the region by Europeans in the sixteenth century; and finally

25 Compare Gallop 1997: 73-75. By convention, Sloane "Oriental" manuscripts held in the department of the British Library now known as Asian and African Collections are referred to simply as "Sloane" followed by the manuscript number, for instance Sloane 3115, but Sloane manuscripts held in the Western Heritage department include the prefix MS before the number, for instance Sloane MS 2117.

26 Wood 2005: 221-222.

27 Sloane MS 3323, ff. 270r-272v. 
Dutch, the tongue of the dominant mercantile power in the archipelago from the seventeenth century. Equally varied are the scripts encountered in the twelve manuscripts, which include Balinese, Javanese, Lampung, Burmese, Khmer with a Thai tinge, Lao, Arabic in its original form as well as extended versions for writing Persian, Malay, and Javanese, the Vietnamese Han Nom characters derived from Chinese, and Roman script. Writing supports range from palm leaf and bamboo to Javanese tree-bark paper (dluwang) as well as European rag paper and Chinese paper, dyed yellow and illuminated with silver. Book formats include palm leaf bundles and bound paper codices in both portrait and landscape format, and documents are written on pieces of palm leaf and bamboo, as well as in scroll format. Seals are blind-stamped on palm leaf, stamped on paper in black ink and red ink, and on cloth and paper in red wax.

In their contents, these manuscripts evoke vividly and coherently the two main European preoccupations of the age in which they were collected. The mercantile thrust which gave birth to the English and Dutch East India Companies at the beginning of the seventeenth century is reflected in the trading permits and financial accounts accumulated. On the other hand, religious zeal is manifest in an interest in the canonical and liturgical works of the major world religions which had taken root in Southeast Asia: Buddhism and Hinduism which had travelled from India, Islam from its birthplace in Arabia, and most recently Christianity by way of Europe. Four different calendrical systems are used in these texts: the Burmese/Maghi Era, the Gregorian calendar, the Javanese Saka Era, and the Chinese zodiac calendar. Finally, as part of the foundation collections of the British Museum and its Library, all these manuscripts certainly predate 1753 - in some cases by a considerable period of time - and include some of the oldest known representatives of their genres.

\section{AFTERWORD}

All the Sloane manuscripts from Indonesia, and the Vietnamese scroll, are fully digitized and accessible through the British Library's Digitised Manuscripts website http://www.bl.uk/manuscripts/Default.aspx. From June 2018 to early 2019 eight of these manuscripts were on public display in the Southeast Asia exhibition case, outside the entrance to the Asian and African Studies Reading Room, in the British Library in London (see Figure 13). ${ }^{28}$ 


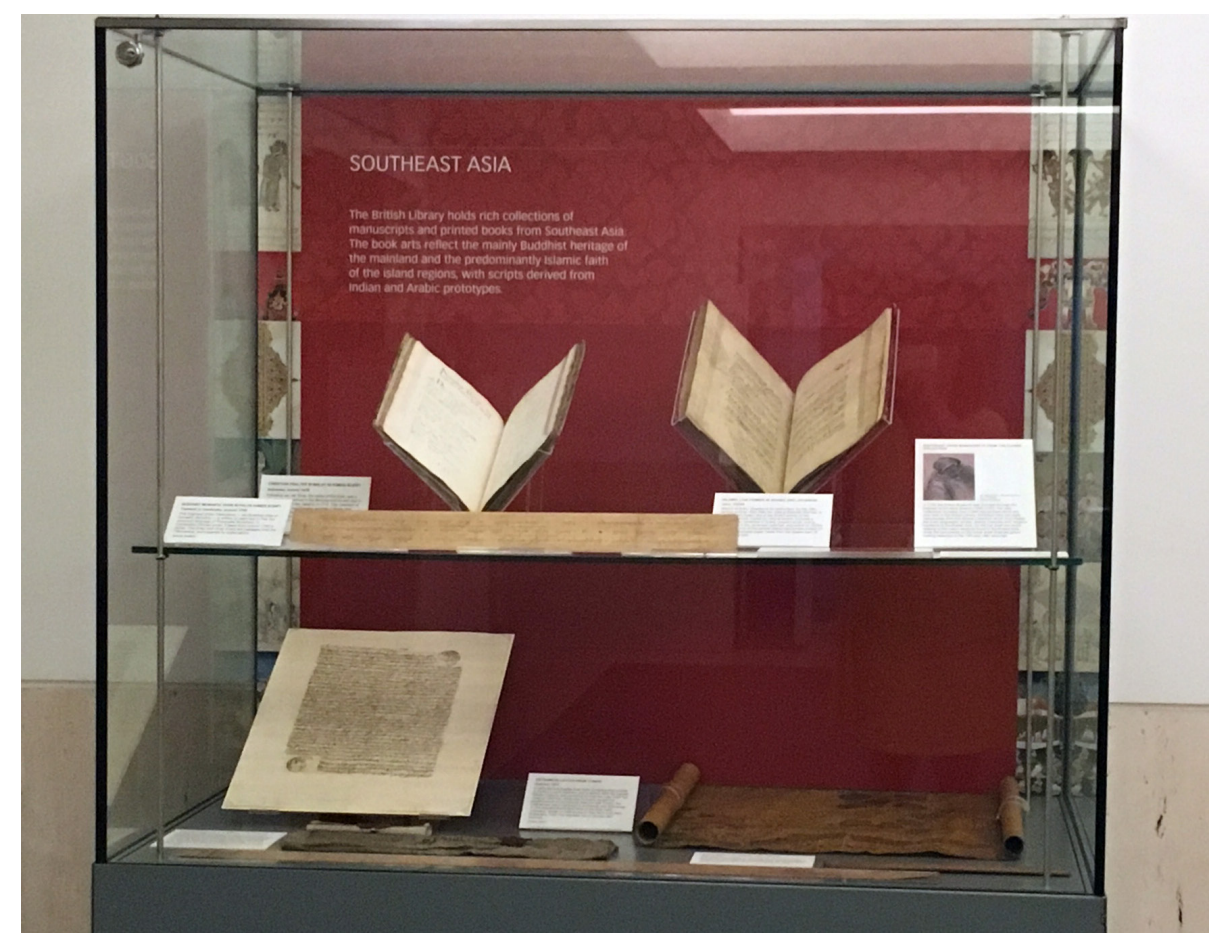

Figure 13. Southeast Asian manuscripts from the collection of Sir Hans Sloane, on display in the Southeast Asia exhibition case outside the Asian and African Studies Reading Room, British Library, June 2018.

\section{REFERENCES}

Arps, Bernard and Willem van der Molen (eds). 1994. Serat Lokapala kawi: an eighteenth-century manuscript of the Old Javanese Arjunawijaya by Mpu Tantular; A facsimile edition of manuscript Cod.Or. 2048 in the Library of Leiden University. Leiden: Indonesian Linguistics Development Project (ILDEP) in co-operation with Legatum Warnerianum in the Library of Leiden University. [Manuscripta Indonesica 3.]

Gallop, Annabel Teh. 1997. "A 17th-century Malay miscellany; Two new discoveries in the British Library", in: Tradisi penulisan manuskrip Melayu, pp. 71-86. Kuala Lumpur: Perpustakaan Negara Malaysia.

Gallop, Annabel Teh. 2015. “Dates on Malay seals; A study of Arabic numerals from Southeast Asia", Jurnal Filologi Melayu 22: 89-114.

Herbert, Patricia. 1989. "The making of a collection; Burmese manuscripts in the British Library", The British Library Journal 15(1): 59-70.

Hunt, Arnold. 2012. "Sloane as a collector of manuscripts", in: A. Walker, A. MacGregor, and M. Hunter (eds), From books to bezoars; Sir Hans Sloane and his collections, pp. 190-207. London: The British Library.

Khazeni, Arash. 2018. "Merchants to the Golden City; The Persian Farmān of King Chandrawizaya Rājā and the elephant and ivory trade in the Indian Ocean, a view from 1728", Iranian Studies 51(6): 933-945.

Meij, Dick van der. 2017. Indonesian manuscripts from the islands of Java, Madura, Bali and Lombok. Leiden: Brill. 
Mohamad Jajuli Rahman. 1986. The Undang-Undang; A mid-eighteenth century Malay law text (BL Sloane MS 2393); Transcription and translation. Canterbury: University of Kent, Centre of South-East Asian studies.

Ricklefs, M.C. and P. Voorhoeve. 1977. Indonesian manuscripts in Great Britain. Oxford: Oxford University Press.

Rieu, Charles. 1879. Catalogue of the Persian manuscripts in the British Museum. Vol. 1. London: Longmans.

Supomo, S. 1977. Arjunawijaya; A kakawin of Mpu Tantular. 2 vols. The Hague: Martinus Nijhoff. [Bibliotheca Indonesica 14.]

Wood, Frances. 2005. "Chinese books in the British Museum", in: Ming Wilson and Stacey Pierson (eds), The art of the book in China, pp. 219-230. London: Percival David Foundation of Chinese Art, SOAS, University of London. Yahya, Ismail, Moh. Abdul Kholiq Hasan, and Farkhan. 2018. Penerjemahan manuskrip Masa'il at-ta'lim ke dalam aksara pegon pada abad ke-17 M. Sukoharjo: IAIN Surakarta.

BLOG POSTS

All published on the British Library's Asian and African studies blog < https:/ / britishlibrary.typepad.co.uk/asian-and-african/index.html>:

Chonchirdsin, Sud. 2018. "A Vietnamese Lord's letter to the East India Company", 15-10- 2018.

Gallop, Annabel Teh. 2013. "Malay manuscripts in the Sloane collection", 4-11-2013.

Gallop, Annabel Teh. 2018a. “Two Christian manuscripts in Malay”, 1-4-2018. Gallop, Annabel Teh. 2018b. "Javanese manuscripts in the Sloane collection", 19-11-2018.

Gallop, Annabel Teh, San San May, Jana Igunma, and Sud Chonchirdsin. 2018. "A new display of Southeast Asian manuscripts from the Sloane collection", 12-9-2018.

Sudarma, Ida Bagus Komang, Wayan Jarrah Sastrawan, and Arlo Griffiths. 2018. “Sir Hans Sloane's Old Javanese manuscript, Sloane 3480", 20-6-2018. 